\section{Property rights and methods of nomocratic planning}

Planning Theory 2016, Vol. 15(3) 274-293 (C) The Author(s) 2015

Reprints and permissions: sagepub.co.uk/journalsPermissions.nav DOI: $10.1177 / 1473095215583749$

plt.sagepub.com

(SAGE

\author{
Aleksandar D Slaev
}

Varna Free University, Bulgaria

\begin{abstract}
This paper examines the methods of planning of complex systems. More precisely, it applies property rights analysis to the methodology of nomocracy, a leading branch of the theory of complexity in planning. To study the methodology of planning, the paper focuses on its objectives and methods, as well as the characteristics of nomocratic rules. It briefly examines the literature on the methods of planning of complex systems, the methods of the nomocratic approach, and the methods of regulation theory. It then develops a theoretical structure of the methodology of nomocratic planning by employing property rights analysis and finds that the purpose of nomocracy is the allocation of entitlements. Finally, to emphasise the importance of property rights, it discusses some specific findings of Holcombe's work "Planning and the Invisible Hand". Holcombe's work is a well-developed study of the relevance of the nomocratic approach to market functions; planning practices, such as zoning; and topical issues of contemporary urban development, such as sprawl and related new urbanism/smart growth principles. This paper focuses on Holcombe's particularly critical view of the latter. However, while the application of property rights analysis fully supports Holcombe's understanding of the positive connection between nomocratic planning and the market, it also leads to a more favourable view of zoning and new urbanist principles. The paper concludes that the main objective and defining characteristic of nomocratic rules is that they serve to allocate property rights over commonly owned resources.
\end{abstract}

\title{
Keywords
}

methodology of planning, nomocracy, planning and regulation, planning of complex systems, property rights

\section{Introduction}

At the end of the $20^{\text {th }}$ century, planning theory confronted basic questions such as how to plan for multiple end users who have different and often contradicting interests, how to balance market forces, and how to plan given constant social and economic change and

\section{Corresponding author:}

Aleksandar D Slaev, Faculty of Architecture, Varna Free University, KK Chaika, Varna 9007, Bulgaria.

Email: slaev@vfu.bg 
high levels of uncertainty. Such questions emphasise the complexity of social structures; thus, the theory of planning of complex systems has gained momentum over the past decades. Within this framework, the concept of nomocracy, developed by Hayek (1973, 1976) and elaborated by Moroni (2007, 2010, 2014a) and others, has thrived in recent years. However, this concept raises difficult issues that have been treated differently by authors such as Alexander et al., (2012). It is not an easy task to discern the nature of the nomocratic approach as opposed to teleocratic management. In prior work (Slaev, 2014a, 2014b), I proposed an explanation of the essence of the two approaches, based on the theory of property rights. In contrast, this paper examines key features of the methodology (i.e., the objectives and methods) of nomocratic planning. To do this, I employ the same approach I used to examine the essence of planning: property rights analysis.

This paper argues that the main objective of nomocratic planning is to properly allocate common and public property rights. Nomocratic planning is planning relevant to complex social systems. Social systems can be simple or complex. A system of one individual or one firm is simple, because all property rights belong to the person or the firm (Slaev, 2014b). Planning in such a system is teleocratic. However, we wouldn't typically characterize a system of one individual as "social". For the purposes of this research, a "social system" is any group of two or more individuals, a collective or stock company, a club, a community, or a society. Thus, according to this paper, any social system is a complex one insofar as the property rights in it belong to more than one person, so it requires nomocratic planning (Slaev, 2014b). Nevertheless, the difference between simple and complex social systems may be relative, as explained in the first section.

In the first part of the paper, I argue that the methodology of the nomocratic approach serves several key objectives: identifying and defining property rights (entitlements), allocating them by defining and imposing relevant rules/regulations, and managing common property under the direction of the central body through teleocratic planning. To support this assertion in the context of urban management, in the second part of the paper, I examine Randall G. Holcombe's (2013) article, "Planning and the Invisible Hand". Although Holcombe's work is a particularly useful example of applied nomocracy, it does not employ property rights analysis. I argue that such an analysis might well lead to conclusions on issues such as zoning and principles of new urbanism that are quite different from Holcombe's findings.

\section{Literature on the methodology of planning of complex systems}

This section examines the literature on the methodology of planning complex systems, particularly the nomocratic approach. This review reveals that the theory of nomocracy has not yet clearly identified the characteristic features, objectives and methods of nomocratic rules that distinguish them from other rules governing human activities.

\section{Methods of planning relevant to the management of complex systems}

Defining complex systems is not easy, and even the best definitions may allow for different interpretations and require clarification. Scientists (e.g., Alexander, 1965; Batty and 
Marshall, 2012; Portugali, 2012) define simple systems as closed, i.e. with a fixed number of factors. Such systems exhibit "linear" behaviour (because it can be studied by linear approaches) and "equilibrium-tending" (because in closed systems, equilibrium is easier to establish). In contrast, complex systems are open; they exhibit nonlinear behaviour, and equilibrium is more difficult to establish (Portugali, 2012: 228).

Scientific definitions, however, are always idealised, though to different extents. In practice, a simple system may have non-linear behaviour, and a complex system can be balanced in equilibrium. A key problem is that a system can be simple or complex depending on different criteria. Consider a firm: as an element of the market it is a simple system, and its main function - the production function - is determined by a fixed number of factor inputs. However, at the lower level, when the internal organisation of the firm is analysed, it is a complex system. To explain its behaviour economics, organisation theory and cognitive psychology are needed (Simon, 1982). Hence, the specific scope and criteria of a study are essential in determining whether a system is simple or complex.

The latter consideration does not change the fact that the two types of systems require different planning methods. The classical rational planning method, which is top-down, is relevant to simple systems. In contrast, the planning of complex systems requires a very different approach. What methods, then, are relevant to complex systems that have a number of diverse elements and sub-systems and exhibit non-linear behaviour? Many researchers (Alfasi and Portugali, 2007; Moroni, 2010; Webster and Lai, 2003) argue that complex systems are self-organising and should be managed by rules, not by detailed plans. Alfasi and Portugali (2007) assert that the governance of self-organising cities "should not be based on prediction, but on planning rules" (p. 169). They propose a system of implementation based on laws and rules (instead of statutory plans) that should be implemented by "judge-planners". In subsequent works, Portugali (2012) proposes a three-layered system made up of legislative planning authorities, planning judiciaries, and executive systems and agents.

\section{Methods of nomocratic planning}

The proposition that complex systems require rules instead of specific, detailed planning provisions has been best supported by the theory of nomocracy. This approach was first developed by Hayek in the field of governance and in recent years by Moroni in the field of urban and spatial planning. By opposing nomocracy to teleocracy, Hayek $(1973,1976)$ maintains that the nomocratic approach is relevant to social relations and democratic rule. The natures of these two divergent approaches determine their objectives and methods. Teleocratic planning, as relevant to simple systems, is strictly rational, and its methods are based on "deliberate intervention necessarily via a plan" (Moroni, 2010: 138). Thus, it has to solve mainly technical issues; even when dealing with organisational problems, teleocratic management simply has to flesh out already-established goals. For example, a builder builds a house by strictly following the design plans, and the organisation of construction should also strictly follow the prescribed technology. This is also true for any company producing foods, furniture or machinery. In contrast, nomocratic governance employs rules that are abstract and "independent of any particular result 
aimed at" (Hayek, 1973: 97); such rules are simple, non-directional and predominately negative (Moroni, 2010). For example, a local government may not compel private owners build their houses according to detailed governmental plans, but it may impose rules concerning, say, density and building height. Such rules apply to all development rather than a single particular project, so they are general and abstract.

But does that mean that any abstract, general, purpose-independent rule (Moroni, 2010: 146) would qualify as nomocratic? What distinguishes nomocratic rules from any other rules governing human activities? In fact, the above definitions are not exhaustive, because they define only the general difference between rules and direct provisions, but they do not specify any distinctive features of the rules of nomocracy. The builder of the house should follow not only the design plans, but also the rules of technology; the builder should also comply with setback requirements. Both kinds of rules are abstract and general; i.e., they concern not only a single specific situation, but all relevant situations. However, the former are teleocratic rules, whereas the latter are nomocratic rules.

Still, we can draw some general conclusions when we regard nomocratic rules as "framework instruments" (Moroni, 2014a). By establishing rules, central planning creates a framework or an area of options; thus it nomocratically (i.e., democratically) steers the development of a system. As Hayek (1973) stresses, nomocracy is a method of democratic rule: instead of compelling all individuals to strictly fulfil its direct provisions, a central authority uses regulation to create a framework within which the individuals may operate according to their individual interests (Moroni, 2011). In the example given above, a teleocratic or rational/technical plan would define precisely what building should be built in a plot, leaving no room for individual choice. In contrast, zoning regulations create a framework of maximum built-up area, maximum number of floors, etc., so that private owners have the freedom to build according to their individual interests as long as they remain within the framework. This example underscores one key characteristic of nomocratic rules: they allow the coordination of decentralised agents' interests with the central authority's objectives.

\section{Nomocratic rules and regulation theory}

One useful way to study nomocratic rules is to draw parallels between nomocracy and the theory of regulation, which has rapidly developed in recent decades, particularly in the area of macroeconomic governance (Levi-Faur and Gilad, 2004; Majone, 1994; Scott, 2012). In prior work (Slaev, 2014a, 2014b), I have drawn a relation between nomocracy and regulation (in society). I establish this relation by defining regulation as "deliberately made rules", a term used by Hayek (1973: 45). As researchers have emphasised (e.g., O’Driscoll and Hoskins, 2006), Hayekian rules are implicit in regulation theory; thus, there is a direct connection between nomocracy and regulation. Nearly all authors in this field (e.g., Baldwin, 2008; Black, 2002; Majone, 2010; Scott, 2012) identify rules as a basic form of regulation.

Macroeconomic regulation theory is generally oriented towards the practice of governance. In governmental practice, regulations are classified into two major groups: economic and social (Litan, 2007), with five areas of intervention: environmental controls, health and safety regulations, consumer protection (e.g., restrictions on labelling and 
advertising), employment and labour, and privacy (Taylor, 2000; see also Majone, 2010). Ogus (2009) adds town and country planning, banking and insurance. Each area of application determines its objectives and practical methods. At a more theoretical level, major objectives of regulation in (macro)economic and social governance are to protect competition, to limit the power of private monopolies, to ensure national security, and to provide insurance and manage risk (Black, 2002; Jordana and Levi-Faur, 2004; Majone, 2010).

Thus the general goal of regulation is to correct market failures and externalities (Black, 2002; Slaev, 2012) and to realise public goals (Christensen and Lægreid, 2005). The methods and instruments of regulation are rules: "legal, 'quasi-legal', non-legal, universal, sectoral, bilateral", "financial, market-based, [and] information instruments", and "monitoring and sanctioning" tools. They are used to structure, frame, enable, coordinate or order the subject of regulation (Black, 2002: 12).

\section{Fischel's zoning theory}

In his outstanding study The Economics of Zoning Law, Fischel (1985) states that zoning is a form, an instrument, a method or an institution of regulation in the area of spatial development. Other methods or institutions include "private covenants, extended nuisance laws, [and] public acquisition of development rights" (p. 231). To clarify the methods of regulation embodied in zoning, Fischel stresses that zoning is a collective property right. In developing an insightful theoretical construct, Fischel also remains close to issues of practice; thus the goals of zoning that he identifies are practical as well: maintaining environmental quality, improving residential conditions, reducing nuisances, and raising funds through local taxes.

\section{Two forms of planning for the two "sub-areas" of nomocratic governance}

Rules and regulations are not the only methods of the nomocratic approach. Moroni (2014a) finds that nomocracy may use teleocratic methods for specific purposes, such as managing public property. As Moroni (2014a) puts it, nomocracy employs rules for "regulating others" but also employs teleocratic methods when "planning for itself". Alexander et al., (2012) also assert that nomocracy is not comprised only of rules. More specifically, Holcombe (2013) maintains that while local governments must rely on nomocratic law governing private entities to prevent nuisance, they should be much more focused on the management of "their own activities", i.e., the development of infrastructure.

Similar conclusions in different forms appear in many other sources that do not directly relate to the theory of nomocracy. Bertaud (2003) identifies three main groups of planning instruments used to ensure cooperation with the market: development of infrastructure, regulations, and local taxes and fees. The first is a teleocratic tool, whereas the latter two are nomocratic. Adams and Tiesdell (2010) assert that spatial planning affects market processes through three types of policy instruments: market-shaping, marketregulation and market-stimulation instruments. A closer look at all three types reveals that they comprise both teleocratic and nomocratic tools. 
To summarise this section of the paper, the theory of nomocracy holds that complex systems (particularly social systems) should be governed via rules, not direct provisions. However, government should use direct provisions (i.e., the teleocratic approach) to manage its own responsibilities: the development of infrastructure and public properties. Many researchers, especially those working in the theory of regulation, claim that rules/ regulations must be reduced and minimised. A reasonable conclusion is that some rules/regulations are useful, but many others are not. This raises the question of what rules/regulations are needed. Thus far, the theory of nomocracy has not defined the specifics of nomocratic rules. However, it has established that nomocratic rules should "apply equally to everyone ... as long as such use does not create negative externalities" (Moroni, 2014a; emphasis added). Moroni's findings also imply that rules should facilitate cooperation between the goals of the central body of a system and those of the decentralised agents. The theory of regulation suggests that social and macroeconomic rules seek to prevent or correct market failures or accomplish public goals. In the next section, I argue that we must turn to the theory of property rights for a more detailed answer to the question about the specific characteristics of nomocratic rules. Fischel's study provides a sound basis for research in this area; Alfasi and Portugali (2007), Holcombe (2013) and others emphasise the role of legislation and courts, which also implies the importance of property rights. Analysis of the connection between property rights and different forms of organisation, nomocratic governance, planning and regulation has been a major focus of recent research conducted by Andersson, Foldvary, Lai, Moroni and others (Andersson and Moroni, 2014).

\section{Objectives and methods of nomocratic planning in light of property-rights theory}

To analyse the objectives and methods of nomocratic planning in light of property-rights theory, we must emphasise the significance of ownership over the resources involved in a human activity. Clearly, an activity is possible only if the resources necessary for its execution are provided, which evokes the issue of property rights (entitlements). Barzel distinguishes between economic and legal property rights, defining economic property rights as "the individual's ability, in expected terms, to consume the good (or the service of the asset) directly or to consume it indirectly through exchange" (emphasis in original). Thus economic property rights are "the end (that is, what people ultimately seek), whereas legal rights are the means to achieve the end" (Barzel, 1997: 3). In this paper I employ Barzel's definition.

The connection between economic and legal rights merits further examination. Even when a property right is not fixed in written form, e.g., in a title deed, contract, regulation or law, it should still be recognised by the parties to a market deal. Otherwise, a voluntary exchange is impossible. In general, an individual's right does not exist unless it is recognised by society, or at least by those involved in related activities. But an individual's right should also be based on any kind of contribution, or on some service or merit: the individual should have paid for the good's value, should have sacrificed effort and time, or should possess a merit that entitles the individual to have someone else provide a contribution on his or her behalf (e.g., by being an heir or by qualifying for a social health 
care system, insurance system, or a subsidy programme). Without relevant contribution or merit, the right would not be recognised and would cease to exist. Therefore, providing contribution or possessing merit is essential in establishing entitlements and should be an important focus of analysis.

\section{The main objective and methods of nomocratic planning}

Simple systems are managed through teleocratic approaches because all resources (including labour, administrative powers, etc.) belong to a single owner - an individual, a firm or any other kind of entity. Therefore, she, he or it defines all development goals and can plan all actions in detail with a maximum level of certainty (Slaev, 2014b). The owner has to solve only technical problems, and the relevant method of planning is rational planning.

Still, it should be stressed that such a system may be an element within a complex system - as explained in the first section - and in this case, planning will not only have to solve technical problems, but also deal with competitors, customers, neighbours, etc. But then the "single owner" criterion is not met, so the system at this scale is actually an open, complex one. The system will remain closed and simple only for activities that use only resources owned by this individual owner.

In a complex social system, however, the property structure is much more complicated, as social activities involve more than one individual. A key feature of a complex social system is that some resources (e.g., space) are subject to shared/joint, common or public ownership (Slaev, 2014b). If Barzel's definition is adapted, when two or more people possess shared/joint or common property, they share the ability, to consume or to use a resource or any of its attributes directly or through exchange. But because the coowners have different needs and goals, common resources cannot be managed simply by employing rational/technical planning. First, the co-owners need to agree on which of them are entitled to use the joint property or any part of it, within what limits, under what conditions, etc.

Smaller groups of co-owners would allocate entitlements directly, as in Barzel's (1997: 57-58) example of two drivers who share ownership of a taxicab. However, larger groups or communities of co-owners would need a central body to manage and allocate common property rights (Demsetz, 1967; Slaev, 2014b). In fact, co-owners transfer parts of their individual entitlements to the central body - a small management group of individuals, who now become "de facto owners" (as Demsetz, 1967: 358, has put it) of certain common property rights (e.g., management rights). As a result of this delegation of powers, the central body now will allocate entitlements on behalf of all co-owners. For example, municipal planners impose zoning regulations on behalf of the local government, and thereby on behalf of local voters. By analyzing contractual communities, Moroni (2014b) provides an insightful explanation of the forms of transfer of property rights from co-owners to different types of organisations. Hence, either directly or indirectly through a central body, the first task of co-owners is to allocate property rights.

This is the main assertion of this paper: the primary objective of nomocratic planning is to allocate property rights, i.e., the rights to use and manage resources, the rights to control, the corresponding liabilities, etc. (Andersson, 2014: 21 identifies four types of 
property rights: rights of exclusion, rights of use, rights of income, and transfer rights.) The role of nomocratic planning is thus similar to the role of the market as defined by Coase (1960). Coase demonstrates that property rights to all resources tend to be allocated optimally through market function. The first condition for market allocation is the proper definition of entitlements. Still, for a market transaction to take place, each party should be the exclusive owner of the resource(s) exchanged; otherwise she or he may not take part in the transaction. Thus, according to Coase, the definition of property rights will result in private ownership and resources will be traded. But for many resources, private ownership is either not possible (e.g., neighbourhood air quality) or not viable (e.g., an apartment building staircase). In situations of co-ownership, co-owners cannot trade their property rights freely, either because they are in a monopolistic/monopsonic relationship (if there are only two co-owners), or because the rights of the other coowners limit their own individual rights. Thus, the proper allocation of entitlements in situations of joint or common ownership can be achieved only through nomocratic planning (Slaev, 2014b). In fact, this is its main purpose.

However, the methods of nomocratic governance should be relevant to its two basic forms: 1) coordinating the actions of individuals and private entities, and 2) managing the common/public resources in the central body's domain. Obviously, these two forms of nomocracy require different methods of management. But no matter how different the methods are, their main objective is still the same: to allocate common property rights.

As already emphasised, the first form of nomocratic governance is nothing more than developing and imposing rules of conduct, i.e. regulations that define the rights to use resources as well as the rights to manage, control and transfer them. Regulation thus allocates property rights among the decentralised agents and also between them and the central body. For instance, regulations imposing ecological requirements limit the rights of companies to use their resources in ways that create pollution. The power of control, which is a type of property right, is transferred to the government, a state agency or a third party. Another example is zoning. When zoning regulations prescribe certain uses or prohibit others, certain management rights of private owners are transferred to the local authorities. The authorities exercise their powers on behalf of local voters, thus actually local residents manage collectively specific property attributes (e.g. maximum height or density). Thus zoning is a "collective property right" (Fischel, 1978, 1985). Similarly, Andersson (2014) finds that "[u]rban planning is about the development and rearrangement of property rights" (p. 34).

The allocation of property rights is also the main task of the second form of nomocracy, which involves the management of public properties placed under the central body's direction. As some authors have stressed, when managing public resources, the central body employs teleocratic measures within the nomocratic approach. But actually, the teleocratic plan comes into play only after the (re)allocation of entitlements. For example, if the residents of a new suburb need a new water-supply main or sewer, they must agree on the provision of necessary land resources and funding for construction. They will have to transfer property rights over particular strips of land, and they will have to raise funds. In such cases, fundraising is accomplished by taxing, but determining who provides the strips of land is always problematic, for several reasons. Land is of great value, individual contributions should be based on a fair solution, and so on. 
Compared to the issues of fundraising and provision of land, the problems of technical (teleocratic) plans are much easier to solve. Technical plans come second also because they are financed by the funding raised.

These considerations emphasise the key importance of contribution in assigning property rights. If common goods are consumed without providing proper contribution/compensation, then they are at least partly "captured", as Barzel (1997) puts it. Such entitlements are unstable and distort the market system. This suggests that the issue of contribution/compensation is very often the critical factor in the proper assignment of entitlements to common and public resources.

A specific and explicit form of these relations and mechanisms is observed by Moroni $(2014 b)$ in contractual communities. Individual property rights over dwelling units in such communities are subject to contractual arrangement, "a sort of local private constitution" (p. 39), "while a range of common areas (squares, streets, parks, sports grounds, and so on) are collectively owned through the association of which the homeowners are members" (p. 42).

This section thus leads to the conclusion that the primary and immediate goal of nomocracy in planning any activity is to properly allocate property rights over jointly/ commonly owned resources. For this purpose, three methodological steps should be followed. At the first step, all involved parties, with their interests and existing property rights, should be identified, and these rights should be adequately defined, especially the more difficult joint/common/public property rights. The adequateness of the definition also means that the level of precision in identifying the involved parties and their interests varies depending on the importance (the total value) of the interests and the costs of identification. The importance of common resources such as clean air, tranquillity and sunlight to residents in a neighbourhood is great, and residents are easily identified, so their entitlements to these resources are well defined. The access to parks in a distant neighbourhood is not that important to strangers, and identifying them is particularly costly, so rights are imprecisely defined.

At the second step, the defined property rights must be properly allocated through regulation, i.e., by employing nomocratic rules. Imposing teleocratic plans fails, because, as Holcombe (2014) notes, "despite the attempts of planners to control development in a top-down type of planning environment, the actual development process is bottom-up" (p. 240). In contrast, zoning regulations are tools of bottom-up nomocratic planning, particularly if not developed by teleocratically minded planners. Regulations determine the access to common resources and the powers of individual owners to manage their properties, thus allocating rights of use and management among different groups of owners and the community. In the third step, the items of property that are placed under the full control of the central body, i.e. common and public properties, should be planned, developed and managed - both teleocratically (i.e., through rational and detailed plans, such as the technical plan for the construction of a road) and nomocratically (e.g., through traffic regulation or rules for use of public parks).

These three steps are easy to define but difficult to implement, and planners typically overlook the property rights issues. For instance, when developing a city's master plan, they generally plan for what they believe is the "best" or the "proper" development of the city based on their professional expertise. However, they tend to rely on 
the wrong type of professionalism, often ignoring the market (Adams and Tiesdell, 2010; Bertaud, 2014; Slaev et al., 2012). Genuine professionalism would involve properly allocating entitlements and facilitating favourable conditions under which these rights could be exercised. Professionalism that ignores property rights and attempts to impose technical solutions on private owners because planners believe that they as professionals "know better" is misguided, at best (Holcombe, 2014), as explained in the previous paragraphs. Such attempts are pointless, because even the best solutions are meaningless if not accepted by the owners of property rights, who determine actual development. Without property rights analysis, planners cannot develop viable plans. This omission is probably one of the most common reasons for planning failures. Since different groups and social strata have different property rights, they have divergent interests in development, which often results in critical assessment of planning. A Google search for "planning failure" on October $14^{\text {th }}, 2011$, produced 4.7 million results; on August 31 st $2014,92.4$ million results. As I show in the next section, even the most reasonable nomocratic approach may lead to inadequate solutions when property rights analysis is neglected.

\section{Property rights and methodology of nomocratic planning in the context of urban development}

This section discusses Holcombe's (2013) paper "Planning and the Invisible Hand", a particularly useful application of the theory of nomocracy to topical issues of urban development. Below, I briefly outline Holcombe's main findings on zoning and urban development issues, such as sprawl, as well as on related smart growth/new urbanism approaches. I then apply a property rights analysis in order to demonstrate how such an analysis can alter the conclusions we draw regarding these practical issues.

Holcombe's main argument is that "sometimes planning [i.e., top-down teleocratic planning] will work to counteract market forces", so teleocracy and markets are adversaries. "[O]ther times planning [i.e., bottom-up nomocratic planning] will build on the spontaneous order created by the market", and "the two will be allies" (p. 201). Similarly, Holcombe finds that governments tend to plan "too much of the affairs of market participants" but "insufficiently [plan] their own activities". Regarding the activities of private owners, Holcombe repeatedly asserts that governments should not employ zoning. Instead, the market mechanism should be "augmented by the common law doctrine of nuisance" (p. 202). Concerning "their own activities," governments' main role should be to plan and develop infrastructure networks, especially transportation corridors. In this way, governments could be successful nomocratic planners, creating an optimal framework for market development.

Holcombe's work is a well-developed case that demonstrates the relevance of the nomocratic approach to the market. The connection between the two is implicit in Hayek's perception of grown (spontaneous) order (Hayek, 1973, 1976). It is implicit in the idea that complex social systems are self-regulating (Alfasi and Portugali, 2007; Moroni, 2010; Portugali, 2012) and that market society is such a system. In prior work (Slaev, 2014b), I propose that nomocratic rule is relevant to the market because it is the instrument used to manage commonly owned resources. As Webster and Lai (2003: 
52-61) observe, markets need the state. In fact, they need nomocracy as an ally because without nomocracy, markets cannot employ commonly owned resources.

Many of Holcombe's other conclusions are correct as well. Because of their coercive powers, governments do tend to overplan the use of resources owned by private persons and entities (e.g., private lands). Such interventions limit the freedom of decentralised agents and thus are detrimental to markets. On the other hand, when a government properly manages the development of its own property (e.g., infrastructure), planning is the market's ally, as it improves the access of decentralised entities to all kinds of resources.

However, if property rights are not properly defined, the improved access is not necessarily beneficial to the market. What if a thief gains access to a museum and steals a painting? In Barzel's terms, the thief has captured economic property rights over the painting, because he may consume the good indirectly through exchange. Luckily, property rights over the painting are usually well defined, and this act will be recognized as a theft rather than a market transaction. But as Barzel notes, for many other goods, especially public goods, property rights are not clearly defined. They can be captured and improperly privatised without the act being recognized as theft. Examples are the loss of street space in spontaneous settlements due to unauthorised housing development, as well as many forms of "free-riding". Then who is in charge of defining entitlements over jointly owned resources? The market? Coase stresses that markets can allocate property rights efficiently if they are properly defined, but he does not say who is in charge of their definition. Markets alone cannot do that, especially when it comes to common properties, as explained below. Rather, nomocratic governance and nomocratic planning ought to carry out this function.

To point out some shortcomings of Holcombe's findings that result from his omission of property rights analysis, I start by discussing his criticism of zoning. Holcombe (p. 202) finds that zoning "has several drawbacks compared with the law of nuisance in preventing incompatible uses of land". First, "zoning may allow incompatible land uses"; second, "it gives everyone in the political jurisdiction" (i.e., the planning authorities) more power than private parties have (p. 203). In fact, the problem concerning both drawbacks is who defines the (in)compatibility of uses and who has the power to decide and impose the actual land use. Does the institution in charge have the right to do so, is it fulfilling its role, and has it done it properly? The allocation of property rights is the ultimate goal of both zoning and nuisance law, but neither one automatically guarantees that entitlements are properly allocated. Fischel (1985: 126-127) analyses different aspects of the relation between zoning and nuisance law and argues that the essence of zoning is also to avoid nuisance. To my understanding, the main difference between zoning and nuisance law is in the power of entitlements. Entitlements enacted by nuisance law have greater power, whereas entitlements assigned by zoning are of relatively lower significance, and improper assignments can occur more easily. Still, both zoning and nuisance law are nomocratic forms of governance because both define rules and do not specify direct provisions such as precisely what building must be built. Therefore, both may define (in)compatibility of uses and exercise control powers properly or improperly, depending on whether entitlements are properly assigned.

Two further objections are often raised to underline the essential difference between zoning and nuisance law: that zoning tries to solve the problem of colliding land uses 
before the collision occurs, and that zoning is attached to a specific area of land, whereas nuisance law is not. Both objections speculate on the characteristic features of both mechanisms, features that are obvious in the case of zoning but less obvious in the case of nuisance law. Concerning the first objection, to solve a problem of collision of land uses, rules of nuisance law like zoning ordinances exist before the collision occurs. Concerning the second, provisions of nuisance law, too, often refer to geographic areas of application and always refer to the area of a jurisdiction, so there is no essential difference between nuisance law and zoning; the difference is merely formal.

The main problem with Holcombe's criticism on zoning has to do with his recommendation (based on Coase, 1960) to achieve optimal allocation of entitlements through market transactions, which may not work in the case of common property. For market transactions to take place, stakeholders must own individually (privately) the resources subject to transactions. But this is not always the case. In Holcombe's (2013: 204) example of New York City zoning, sunlight is common property. Trading of sunlight in the New York example may happen only if certain problems are solved. One key problem is that the neighbours who are the co-owners of sunlight value this resource differently; thus its price is unknown. A buyer (e.g., a developer of a high-rise building) may try to negotiate with neighbours one by one. This is what Coase would propose, but it would incur high transaction costs. An even bigger problem is that one owner actually has grounds to sue another owner, if the latter has "sold" the common resource (sunlight) at a price lower than the price bid by the former-or, even worse, without sharing the revenue - and thus has seized shares from other co-owners. To solve this bigger problem, the co-owners of sunlight have to cooperate, organise and agree on a fair price. This would incur costs of organising, which, according to Coase (1937) are the alternative to market transaction costs. In theory, the neighbours may decide to establish a joint company. The allocation of property rights over the common resource will thus be clearly defined. Such an organization will allow the co-owners to take a proper decision on the price issue. However, establishing joint companies for every such reason would be extremely costly; that is why co-owners vote for zoning regulations. Zoning defines development rights and serves as a basis for the definition of development fees. Thus costs incurred to cope with the price issue are acceptable.

In urban planning practice, however, zoning is often implemented by planners who adopt a teleocratic rather than nomocratic approach. For example, teleocratic planners may use zoning to limit densities in central areas, or to require high densities in suburban areas. They do so because their professionalism leads them to believe that they can "teach" area land owners how best to use or develop their own properties. Planners' unconscious goal is thus to protect owners from themselves. In this case, Holcombe is no doubt right to criticise zoning. However, planners may develop zoning regulations to protect other land owners' interests by preventing nuisance. High densities may be unacceptable to residents in suburban areas (Fischel, 1985) but acceptable to residents of central areas, because the latter may benefit from better access to jobs and services. Mediation between co-owners of common property (e.g., access or sunlight) is what distinguishes nomocratic rules from other rules. As long as planning assumes the role of a mediator between the interests of urban owners, zoning is not harmful; in fact, it is useful and necessary in the urban-development market. 
Holcombe also discusses topical trends in modern urban development and planning, such as suburbanisation, sprawl and the smart growth/new urbanism movement. He is particularly critical of that movement, which is aimed at "creating more compact urban development with higher population density, mixed use development, and shifting individuals from automobile travel to alternative means of transportation". Holcombe emphasises that planning might not succeed in overriding the market and discusses in detail the collision of each of these smart growth aims with the "invisible hand". "As people's incomes increase, one of the things they want to buy with their increased incomes is more living space. Thus ... population density will tend to decline as incomes rise" (p. 204). Similarly, people prefer to use their private cars rather than public transport and bikes. Because automobiles are "normal" goods, "people want to buy more of them as their incomes and wealth increase" (p. 205).

Holcombe's treatment of smart growth principles seems to be well grounded in the theory of nomocracy. But again, some of his conclusions are not fully relevant because he does not apply property rights analysis. In employing such an analysis in the next part of this section, I support a view popular among many planners and economists: that suburban settlers excessively consume transportation infrastructure and natural resource amenities because those resources are unpriced or underpriced in peri-urban areas (Anas and Rhee, 2006; Arnott and Small, 1994; Brueckner, 2000; Lindsey and Verhoef, 2000). The main reason for such problems with pricing is improper assignment of entitlements. Thus, contrary to Holcombe's observation about the effect of smart growth principles, I argue that the lack of such principles may actually distort the market system.

This discussion focuses on the development of transportation networks in suburban areas, which is directly connected to the above-mentioned smart growth issues. More specifically, transportation is a key factor in urban sprawl, falling residential densities and pervasive use of private cars (Holcombe, 2014). The development of infrastructure is also relevant to this research, because it is a public resource under the direction of the centre (the government).

In principle, as Holcombe noted, planning that tries to override the market is inefficient at best. But how can planning successfully cooperate with the market and promote it? Planning should provide favourable conditions under which market participants can operate in accordance with their market interests. Yet markets are composed of multiple and diverse stakeholders. Too often, planning provides favourable conditions for some stakeholders at the expense of others. For example, consider infrastructure. It facilitates market performance because it enables individuals and firms to be active market participants. However, since local government funds are limited, developing infrastructure in one area means not developing it in another. Thus, to cooperate with the market, planning must optimally allocate funding for infrastructural development between areas and between market participants. In other words, the government must decide which residents are in greater need of infrastructure (now and in future) and at whose expense funding should be provided. Hence, to be an ally of the market, planning should start with proper allocation of entitlements.

To assign entitlements in using infrastructure, two important questions must be answered: (1) who is going to benefit from the planned development, and (2) who is going to pay for it. As emphasised in the previous section, paying the proper price for a 
resource or making a relevant contribution is often the key issue in assigning property rights. The next paragraphs focus on this issue.

As a public resource, the transportation network is generally funded by the local or central budget, i.e., by all taxpayers of the community or state. There are many reasons it is not normally funded by its direct users. Above all, establishing a system of direct payments would be too costly, so property rights are left in the public domain (Barzel, 1997; Fischel, 1985). However, according to Barzel (1997), legitimate consumers of goods and resources are owners. But to be legitimate, i.e., to be recognised as an owner, a user must have either paid for the value used or consumed or must have provided some other adequate contribution.

The funding of infrastructure by its direct users has been the subject of considerable research focused on congestion or road pricing. Road pricing was reportedly first proposed by the RAND Corporation in 1949. Since then a huge number of studies have been conducted, e.g., Vickrey (1963, 1969), Walters (1961), Verhoef et al. (1996), and Arnott and Small (1994). When tolls or other tools (taxes, fees) are used with the sole purpose of paying for the costs of infrastructural development, the main questions that arise are:

- How to identify the number of potential users (when a toll charge is imposed) or who the users are (when funding is raised by imposing taxes or fees).

- How much users should pay - i.e., what costs should be compensated for?

- How to collect the payments - i.e., through what mechanisms?

- How the income will be used - to develop the network or to compensate for externalities?

A considerable share of the studies in this field address the second question. Although they sometimes address construction costs, they focus mainly on the indirectly incurred costs generated as a result of infrastructural development, i.e., externalities. For instance, Johansson (1997) examines transportation costs due to "congestion, emissions, and the corresponding excessive fuel consumption and emissions due to the congestion". Mankiw (2009) differentiates between costs relating to carbon emissions and local pollution such as smoke, as well as analysing costs due to accidents. In addition, Mayeres (2002) distinguishes three types of environmental costs: air pollution, noise and global warming.

As an economist, Holcombe does not ignore the issue of road pricing. In an earlier book, Holcombe and Staley (2001) acknowledge the positive effect of road charges and HOT (High Occupancy Toll) lanes (pp. 258-259). In the same book, Poole (2001: 5978) outlines more than 20 HOT lane projects in the US. Congestion charging on urban roads was introduced in Singapore as early as 1976. In Europe, the first cities to implement such pricing systems were Bergen, Oslo and Trondheim at the end of the 1980s. Today similar systems also function in London, Stockholm and Milan. These examples demonstrate that tools to raise funding from direct users are not only considered essential to compensate for direct and indirect costs caused by infrastructural development, but are already being implemented increasingly widely to solve such issues.

Challenges regarding the use and cost of externalities relating to transportation infrastructure vary greatly in three principal cases: (a) outside urban areas, (b) in central cities 
and traditional urban areas, and (c) in new suburbs. Road pricing is easiest to enforce on motorways outside urban areas (case a), whereas the pricing systems mentioned above operate in traditional urban territories (case b) where congestion is fiercest. In suburban areas (case c), which are the subject of this analysis, congestion is not a problem except on thoroughfares; still, the issue of financing infrastructural development is essential. Keep in mind that suburban settlers are typically middle class or affluent citizens (Fishman, 1987; Muller, 1981). If the development of suburban street networks is financed by the (local) government, all taxpayers of the community, including socially weak ones, pay for infrastructure that chiefly serves well-off and wealthy suburban residents.

All of the other externalities mentioned above are faced in suburban areas as well. One externality that deserves special attention is the consumption of natural resource amenities. It is not usually listed among the externalities of transportation development, but insofar as it can be assessed, it should be considered the externality with the greatest negative impact (Krautkreamer, 2005). Natural resource amenities include open natural landscapes, unsealed soils, microclimates, biodiversity, etc. The problem with natural resource amenities is that (unlike natural resource commodities) they are not measurable. The fact that natural resource commodities (e.g., petroleum, natural gas, coal, and ore) are measurable, dividable and therefore tradable is the main reason most ecological economists believe that resource commodities are not threatened by unreasonably high rates of depletion (Krautkreamer, 2005). This is because their owners seek to maximise their total returns and sustain only optimal rates of use. In contrast, natural resource amenities are not generally traded on the markets, because they are particularly difficult or impossible to measure (Krautkreamer, 2005; Poudyal et al., 2008). Thus the consumption of resource amenities is not controlled (Krutilla and Fisher, 1985; Rowthorn and Brown, 1995), and such amenities are currently being depleted at critical rates (Krautkreamer, 2005).

To emphasise, there is a direct relation between externalities, underpricing and allocation of property rights. The essence of externalities is that they are costs borne by third parties to a market deal. Since Coase (1960) wrote "The Problem of Social Cost", it has been well established that the best solution to any problems relating to externalities is the proper allocation of entitlements.

Underpricing of resources is another aspect of the problem discussed here. If third parties bear costs incurred by a market deal in which they are not involved, then the parties directly involved in the deal do not pay its full costs. And if the involved parties do not pay the full costs, then resources are underpriced on the market and are used excessively. The actual causal relationship should be stated as follows: improper allocation of entitlements is the main reason that public properties, particularly transportation infrastructure and natural resource amenities, are unpriced or underpriced. Thus externalities, underpricing and problems involving allocation of property rights are inextricably connected.

Property rights analysis also offers the best explanation of the depletion of natural resource amenities. Both resource commodities and resource amenities are natural products, but the former are measurable and ownership rights to them can be established, whereas the latter are not measurable and ownership rights to them remain undefined. 
Clearly, the existence or absence of assigned property rights is a key factor in the way resources are used (Krautkreamer, 2005: 11), in the efficient and economical use of resource commodities, and in the accelerated depletion of resource amenities.

Solving these problems by assigning entitlements to infrastructure and amenities is exceptionally difficult but not impossible. Though slowly and with great effort, instruments such as toll charges, development fees, impact fees, and taxes are being developed. However, a discussion of specific tools falls outside the scope of this paper. The goal here is to emphasise the significance of property rights for the methodology of nomocracy.

Allocation of property rights is at the root of virtually all issues involving the use and management of common or public resources, including problems relating to the development and use of transportation networks, as well as the preservation, maintenance and use of natural resource amenities. Regarding the aims of smart growth that Holcombe so severely criticises, the key factor is whether suburban residents pay the full price for all the elements and attributes of infrastructure and natural resource amenities that they are using or consuming. If they do pay the full price, then they are legitimate owners, and central planning should not try to shift them "from automobile travel to alternative means of transportation" or to impose higher densities. In that case, Holcombe's findings regarding smart growth principles would be correct. However, the preceding discussion suggests that, generally, suburbanites do not pay the full price of infrastructure and natural amenities, because these public goods in suburban areas, as a rule, are underpriced. (In a more recent work, Holcombe, 2014 identifies "the stress on natural amenities" (p. 223) as one of the main "negative effects" of urban growth/sprawl spurred by infrastructural development.) Whereas Holcombe is correct that teleocratic planning is unable to solve these problems, he should recognise that the market is also unable to optimally allocate entitlements over common resources or to properly define their price. While this task is exceptionally difficult, it is also exceptionally important, particularly for the protection of natural resource amenities. And it can be completed only by nomocratic planning.

As the preceding discussion confirms, the methodology of nomocratic planning is subordinate to its main objective of allocating property rights over jointly/collectively owned resources. Concerning the common attributes of individual (private) properties, nomocracy allocates property rights by employing regulations (e.g., zoning regulations). Nomocratic regulations are rules of property management aimed at protecting the interests of all stakeholders and preventing nuisance. Concerning common or public properties, particularly infrastructure, the first step of nomocratic methodology is to define who should be served by the infrastructure networks. The next step is to develop mechanisms for raising funds from the prospective users to pay for infrastructural development and for the consumption of public and natural amenities.

\section{Conclusion}

The goal of this research was to examine key aspects of the methodology of nomocratic planning. The research is based on the premise that property rights are what differentiate simple and complex systems of social activities. In a simple system, all property rights 
belong to a single owner, so the relevant planning method (teleocracy) is strictly rational and has to solve only technical problems. However, in a complex system, entitlements belong to many owners; therefore, the first step is to allocate entitlements. In this paper I have argued that in contrast to teleocratic planning, the first and main objective of nomocracy is to allocate property rights over commonly owned resources by establishing rules. This distinctive characteristic of nomocratic rules is what distinguishes them from other rules governing human activities.

This characteristic has many implications for the role of the nomocratic planner. As a form of governance, nomocracy is bottom-up (Holcombe, 2013; Moroni, 2010) and leaves room for individual freedom (Hayek, 1973, 1976). When allocating property rights, the nomocratic planner does not seek to impose rules on individuals just because the planner as a "professional" knows better. On the contrary, individuals are better informed about their own activities and interests than central planners (Hayek, 1945; Holcombe, 2013); thus nomocratic rules are not meant to protect individuals from their own actions. In fact, they are rules imposed on individuals and individual entities to safeguard the interests of others (i.e., to prevent nuisance) and to ensure the proper use of common resources. This is a defining characteristic of nomocratic rules, their objectives and their methods.

In managing common/public properties under the direction of the central body, nomocratic planning utilises teleocratic methods as well, but its first and main objective is to allocate entitlements and, more precisely, to define the access of each individual to the benefits of common/public properties and to distribute individuals' required contributions. Only after that should the central body employ teleocratic plans to solve the technical issues of development.

If the conclusions of this paper are correct, they suggest a number of further issues that merit research. Property rights over resources comprise the rights to manage them, to process them, to use or consume them, to exchange them, to monitor and control their use and consumption, and to perform other similar activities. Rights also entail corresponding liabilities. Barzel (1997) emphasises the connection between property rights and liabilities, but that connection should be studied in greater depth in reference to specific areas of social interactions such as urban development, economic processes, etc. Also of great significance is the allocation of entitlements between individual co-owners or different groups of co-owners, between co-owners and the central body (Moroni, 2014b), between long-term co-owners and newcomers (Fischel, 1985), etc. In-depth analysis of nomocratic rules and methods is needed because they are so essential to any social interaction or function of human society.

\section{Funding}

The author acknowledges the financial support by the European Union FP7-ENV.2011.2.1.5-1 (TURAS Project) Grant Agreement no. 282834.

\section{References}

Adams D and Tiesdell S (2010) Planners as market actors: Rethinking state-market relations in land and property. Planning Theory \& Practice 11(2): 187-207.

Alexander C (1965) A city is not a tree. Architectural Forum 122(1): 58-62. 
Alexander ER, Mazza L and Moroni S (2012) Planning without plans? Nomocracy or teleocracy for social-spatial ordering. Progress in Planning 77: 37-87.

Alfasi N and Portugali J (2007) Planning rules for a self-planned city. Planning Theory 6(2): $164-182$.

Anas A and Rhee HJ (2006) Curbing excess sprawl with congestion tolls and urban boundaries. Regional Science \& Urban Economics 36(4): 510-541.

Andersson DE (2014) Cities and planning: The role of system constraints. In: Andersson DE and Moroni S (eds) Cities and Private Planning. Cheltenham: Edward Elgar, 19-37.

Andersson DE and Moroni S (eds) (2014) Cities and Private Planning. Cheltenham: Edward Elgar.

Arnott R and Small KA (1994) The economics of traffic congestion. American Scientist 82: 446-455.

Baldwin R (2008) Regulation lite. Regulation \& Governance 2: 193-215.

Barzel Y (1997) Economic Analysis of Property Rights. Cambridge: Cambridge University Press.

Batty M and Marshall S (2012) The origins of complexity theory of cities and planning. In: Portugali J, Meyer H, Stolk E, et al. (eds) Complexity Theories of Cities Have Come of Age. Berlin: Springer, 21-45.

Bertaud A (2003) The China course (lecture course for Chinese urban planners). Available at: http://alain-bertaud.com (accessed 17 August 2009).

Bertaud A (2014) The formation of urban spatial structures: Markets vs design. Working paper \#7, New York: Marron Institute on Cities and the Urban Environment, New York University.

Black J (2002) Critical Reflections of Regulation. London: CARR, London School of Economics and Political Science.

Brueckner JK (2000) Urban sprawl: Diagnosis and remedies. International Regional Science Review 23(2): 160-171.

Christensen T and Lægreid P (2005) Regulatory reforms and agencification. Working paper 6, Oslo: Stein Rokkan Centre for Social Studies.

Coase RH (1937) The nature of the firm. Economica (New Series) 4: 386-405.

Coase RH (1960) The problem of social cost. Journal of Law and Economics 3: 1-44.

Demsetz H (1967) Towards a theory of property rights. The American Economic Review 57: 347-359.

Fischel WA (1978) A property rights approach to municipal zoning. Land Economics 54: 64-81.

Fischel WA (1985) The Economics of Zoning Law: A Property Rights Approach to American Land Use Control. Baltimore, MD: The Johns Hopkins University Press.

Fishman R (1987) Bourgeois Utopias: The Rise and Fall of Suburbia. New York: Basic Books.

Hayek FA (1945) The use of knowledge in society. American Economic Review 35(4): 519-530.

Hayek FA (1973) Law, Legislation and Liberty, Volume 1: Rules and Order. London: Routledge \& Kegan Paul Ltd.

Hayek FA (1976) Law, Legislation and Liberty, Volume 2: The Mirage of Social Justice. London: Routledge \& Kegan Paul Ltd.

Holcombe RG (2013) Planning and the invisible hand: Allies or adversaries? Planning Theory 12(2): 199-210.

Holcombe RG (2014) The rise and fall of growth management in Florida. In: Andersson DE and Moroni S (eds) Cities and Private Planning. Cheltenham: Edward Elgar, 232-247.

Holcombe RG and Staley SR (2001) Policy implications. In: Holcombe RG and Staley SR (eds) Smarter Growth: Market Based Strategies for Land Use Planning in the 21st Century. Westport, CN: Greenwood Press, 251-266.

Johansson O (1997) Optimal road-pricing: Simultaneous treatment of time losses, increased fuel consumption and emissions. Transportation Research Part D: Transport and Environment 20(2): 77-87. 
Jordana J and Levi-Faur D (2004) The Politics of Regulation, Institutions and Regulatory Reforms for the Age of Governance. Aldershot: Edward Elgar Publishing.

Krautkreamer JA (2005) The economics of natural resource scarcity: The state of the debate. Discussion paper 05-14, Washington DC: Resources for the Future.

Krutilla JV and Fisher AC (1985) The Economics of Natural Environments: Studies in the Valuation of Commodity and Amenity Resources. 2nd edn. Washington, DC: Resources for the Future.

Levi-Faur D and Gilad S (2004) The rise of the British regulatory state: Transcending the privatization debate. Comparative Politics 37(1): 105-124.

Lindsey R and Verhoef E (2000) Congestion modeling. In: Hensher DA and Button KJ (eds) Handbook of Transport Modelling. Amsterdam: Elsevier Science Ltd, 353-373

Litan R (2007) Regulation. In: Henderson DR (ed.) The Concise Encyclopedia of Economics. 2nd edn. Available at: http://www.econlib.org/library/Enc/Regulation.html (accessed 20 July 2014).

Majone G (1994) The rise of the regulatory state in Europe. West European Politics 17: 77-101.

Majone G (2010) The transformation of the regulatory State. Osservatorio sull'Analisi di Impatto della Regolazione. Available at: http://www.osservatorioair.it (accessed 6 April 2014).

Mankiw NG (2009) Smart taxes: An open invitation to join the Pigou Club. Eastern Economic Journal 35: $14-23$.

Mayeres I (2002) Taxes and Transport Externalities. Leuven: Center for Economic Studies, K.U. Leuven.

Moroni S (2007) Planning, liberty and the rule of law. Planning Theory 6(2): 146-163.

Moroni S (2010) Rethinking the theory and practice of land-use regulation: Towards nomocracy. Planning Theory 9(2): 137-155.

Moroni S (2011) The role of deliberate intervention on organizations and institutions. Planning Theory 10(2): 190-197.

Moroni S (2014a) Complexity and the inherent limits of explanation and prediction: Urban codes for self-organising cities. Planning Theory. Epub ahead of print 12 February 2014. DOI: $10.1177 / 1473095214521104$.

Moroni S (2014b) Towards a general theory of contractual communities: Neither necessarily gated, nor a form of privatization. In Andersson DE and Moroni S (eds) Cities and Private Planning. Cheltenham: Edward Elgar, 38-65.

Muller P (1981) Contemporary Suburban America. Englewood Cliffs, NJ: Prentice Hall.

O'Driscoll GP Jr and Hoskins L (2006) The case for market-based regulation. Cato Journal 26(3): $469-487$.

Ogus A (2009) Regulation revisited. Public Law 2: 332-346.

Poole RW Jr (2001) Congestion and traffic management. In: Holcombe GE and Staley SR (eds) Smarter Growth: Market Based Strategies for Land Use Planning in the 21st Century. Westport, CN: Greenwood Press, 59-78.

Portugali J (2012) Complexity theories of cities: Implications to urban planning. In: Portugali J, Meyer H, Stolk E, et al. Complexity Theories of Cities Have Come of Age. Berlin: Springer, 221-244.

Poudyal N, Hodges D and Cordel HK (2008) The role of natural resource amenities in attracting retirees: Implications for economic growth policy. Ecological Economics 68(1-2): 240-248.

Rowthorn B and Brown GM Jr (1995) Biodiversity, economic growth and the discount rate. In: Swanson TM (ed.) The Economics and Ecology of Biodiversity Decline: The Forces Driving Global Change. Cambridge: Cambridge University Press, 25-40.

Scott C (2012) Regulating everything: From mega- to meta-regulation. Administration 60(1): 61-89.

Simon HA (1982) Models of Bounded Rationality, vols. 1 and 2. Cambridge, MA: MIT Press. 
Slaev AD (2012) Market Theory of Urbanism, Part 1: Economics of Urban Development. Varna: Varna Free University Publishing House.

Slaev AD (2014a) The forms of ownership as determinants of planning and regulation, e-Journal of Varna Free University 7. Available at: http://ejournal.vfu.bg/bg/pdfs/slaev2.pdf (accessed 3 May 2014).

Slaev AD (2014b) Types of planning and property rights. Planning Theory. Epub ahead of print 26 June 2014. DOI: $10.1177 / 1473095214540651$.

Slaev AD, Anderson RJ and Hirt S (2012) (eds) Planning and Markets in Conditions of Systematic Transformation: Finding a Balance. Journal of Architectural and Planning Research 29(4)

Taylor JB (2000) Principles of Macroeconomics. Independence, KY: Houghton Mifflin College Division.

Verhoef ET, Nijkamp P and Rietveld P (1996) Second-best congestion pricing: The case of an untolled alternative. Journal of Urban Economics 40(3): 279-302.

Vickrey W (1963) Pricing in urban and suburban transport. The American Economic Review 53: $452-465$.

Vickrey W (1969) Congestion theory and transport investment. The American Economic Review 59: 251-261.

Walters AA (1961) The theory and measurement of private and social cost of highway congestion. Econometrica 29(4): 676-697.

Webster CJ and Lai LWC (2003) Property Rights, Planning and Markets. Cheltenham: Edward Elgar.

\section{Author biography}

Aleksandar D Slaev teaches Planning at Varna Free University and the University of Architecture, Civil Engineering and Geodesy in Sofia. He has published books in the area of urban development - "Market Theory of Urbanism, Part 1: Economics of Urban Development", "Economic Modelling in Urban Planning" and "Housing Forms", co-authored "Territorial Planning and Administrative Structure" and "Financing Urban development" and co-edited "Planning and the Market in the Conditions of Systemic Transformation - Finding a Balance" - theme issue of the Journal of Architectural and Planning Research. He is currently working on "Market Theory of Urbanism, Part 2: Market Theory of Planning". 